Published as: Azadi, H., S. SchoOnBeek, H. Mahmoudi, B. Derudder, P. De MaeYer \& F. WITLOX (2011) "Organic agriculture and sustainable food production system: Main potentials". Agriculture, Ecosystems \& Environment. Vol. 144 (1), pp. 92-94.

\title{
Organic Agriculture and Sustainable Food Production System: Main Potentials
}

\author{
Hossein Azadi $^{\mathrm{a} 1}$, Sanne Schoonbeek ${ }^{\mathrm{b}}$, Hossein Mahmoudi ${ }^{\mathrm{c}}$, Ben Derudder ${ }^{\mathrm{a}}$, Philippe De Maeyer ${ }^{\mathrm{a}}$, Frank Witlox $^{\mathrm{a}}$ \\ ${ }^{a}$ Geography Department, Ghent University, Belgium \\ ${ }^{b}$ Faculty of Geosciences, University of Utrecht, the Netherlands \\ ${ }^{c}$ Department of Social Sciences in Agriculture, University of Hohenheim, Germany
}

While organic agriculture (OA) is rapidly expanding, the important question is to understand how OA can contribute to sustainable food production system (SFPS). The SFPS is holistically defined by the American Public Health Association (APHA, 2007) as "one that provides healthy food to meet current food needs while maintaining healthy ecosystems that can also provide food for generations to come with minimal negative impact to the environment. A sustainable food system also encourages local production and distribution infrastructures and makes nutritious food available, accessible, and affordable to all”. Prior to understand the main potentials of $\mathrm{OA}$ in approaching sustainable food system, it is important to note that neither other agricultural approaches; i.e. conventional (characterized by mechanization and the use of synthetic inputs such as chemical fertilizers and pesticides, with an emphasis on maximizing productivity and profitability) and biotechnological (characterized by a range of advanced tools employed to manipulate the genetic make-up of living organisms to make or modify agricultural products), nor OA can address all the aforementioned aspects of the SFPS. In fact, the aspects are complex and appear differently across countries and regions (Carvalho, 2006). One can distinguish bio-physical drivers such

\footnotetext{
${ }^{1}$ Corresponding author. Email: hossein.azadi@ugent.be, Tel. +32 (0)9 26446 95. Fax +32 (0)9 2644985.
} 
as soil degradation and water scarcity while others may more appreciate socio-economic and political drivers such as poverty (Azadi et al., 2011; Bazuin et al., in press; Middleton, 2008; Smith et al., 2000); urban bias in policy making (Jenkins \& Scanlan, 2001); rising food prices (USDA, 2007); and the lack of infrastructures (Middleton, 2008). It is also important to note that none of the aspects stand alone but are interrelated in many ways and may lie on different local and global levels.

When taking into consideration the aspects, especially when facing natural threats (e.g. acute and chronic droughts), in comparison to the other agricultural approaches, OA can make a significant contribution to SFPS as it can better deal with the negative impacts of climate change (Pimentel et al., 2005). It means that food production under organic management is more resistant to the threats; hence, the yield of crops is more stable. This is very important as sudden losses in the yield can considerably manipulate world food prices (Lobell et al., 2011) that might especially affect the poor and vulnerable people in developing countries.

Climatic resilience On the top of conceived advantages for $\mathrm{OA}$, it contributes to climate change mitigation (Scialabba \& Müller-Lindenlauf, 2010; Niggli et al., 2007; Borron, 2006; Hodge, 1993). In general, organic farming systems have a strong potential for building flexible food systems to face uncertainties through farm diversification and enhancing soil fertility (Pimentel et al., 2005; Scialabba \& Müller-Lindenlauf, 2010). Furthermore, as reported by the FAO (2008) OA "assists farmers in adapting to climate change by establishing conditions that increase agro ecosystem resilience to stress. Increasing an agro ecosystem's adaptive capacity allows it to better withstand climate variability, including erratic rainfall and temperature variations and other unexpected events". Therefore, OA can promote sustainable food security. Niggli et al. (2008) point to the inclusion of indigenous knowledge in organic farming as an important way to adapt climate change: "This knowledge 
is important for manipulating complex agro-ecosystems, for breeding locally adjusted seeds and livestock, and for producing on-farm fertilizers (compost, manure, green manure) and inexpensive nature-derived pesticides. Such knowledge has also been described as a reservoir of adaptations". The inclusion of the indigenous knowledge is also something that Muller and Davis (2009) stress as an important characteristic of OA in adaptation and crop development concerning climate change. Finally, OA stimulates the use of local seeds (Kilcher, 2007) which are very often more adapted to local climate conditions (Borron, 2006) though the total mitigation benefits of $\mathrm{OA}$ are hard to measure, as the approach is highly dependent on local environmental conditions and management practices. However, "Should all agricultural systems be managed organically, the omission of mineral fertilizer production and application is estimated to reduce the agricultural GHG emissions by about $20 \%-10 \%$ caused by reduced $\mathrm{N} 2 \mathrm{O}$ emissions and about $10 \%$ by lower energy demand. These avoided emissions are supplemented by an emission compensation potential through carbon sequestration in croplands and grasslands of about $40-72 \%$ of the current annual agricultural GHG emissions" (Scialabba \& Müller-Lindenlauf, 2010).

Soil degradation, drought resistance, and water efficiency The expansion of soil degradation is one of the most serious bio-physical problems at the time being and a serious threat for food production systems (Niggli et al., 2007), especially in developing countries. "Each year about 10 million hectares of crop land are lost due to soil erosion" (Pimentel, 2006). This reduces the available land for food production, especially in Sub-Saharan Africa and South Asia (Lal, 2009). The problem is more critical when we realize that "more than $99.7 \%$ of human food (calories) comes from the land while less than $0.3 \%$ comes from oceans and other aquatic ecosystems" (FAO, 1998 in Pimentel, 2006). Accordingly, some researchers point to soil fertility as the most important dilemma for overcoming the problem of food insecurity, especially in developing countries (Lal, 2009), most importantly in Africa 
(Sanchez, 2002). Improving soil fertility is therefore greatly important. OA contributes positively to the process of encountering soil degradation as it improves soil fertility. The organic farming's techniques (such as balanced rotations, organic amendments and reduced tillage) give a better structure to soil and make it more fertile (Niggli et al., 2007). The fertile soil causes higher soil aggregate stability (Maeder et al., 2002) and this is partly caused by the fact that macro fauna such as worms and ants are not eliminated any longer by pesticides (Niggli et al., 2007). These tiny animals play a crucial role in the production chain: they have positive influence on water infiltration, drainage and water-holding (Giller et al., 2003). Therefore, a better retention of water and resistance to drought is conceived (Muller \& Davis, 2009). Consequently, a dry period will cause less damage to these crops in OA compared with the other approaches. Research even suggests that water capture in the organic farming's plots is $100 \%$ more than conventional plots (Lotter et al., 2003) and organic systems, under dry conditions, often have higher yields than the conventional (from 7 to 90\%) (Ramesh et al., 2005). This is very crucial when we know that only less than $1 \%$ of the world's freshwater is accessible for direct human uses (FBP, 2011) from which, huge contribution (70\%) is used for irrigated agriculture globally (UNESCO, 2003). Given the higher soil organic matters generated by organic practices which retain water more and longer than the soil from conventional systems, organic farming not only less depends on freshwater for irrigation (Fan et al., 2005) but also it can save lots of energy used for irrigation (Schnepf, 2004). The increased water efficiency, drought resilience, and energy saving by organic systems is especially beneficial for farmers in developing countries (Azadi and Ho, 2010). In these countries, the energy sector is not developed enough (Tharakan et al., 2007) and achieving higher local yields especially in times of drought and a reduced dependency on unsustainable water sources for irrigation is a necessary step in alleviating rural poverty and approaching sustainable agricultural system (Ziesemer, 2007). Therefore, the SFPS will be 
reinforced by OA, especially compared with the conventional and biotechnological approaches which: often neglect indigenous knowledge (Niggli et al., 2008); are based mostly on monocultures (which stimulate soil degradation); are less resistant to drought (Ramesh et al., 2005); and use water less efficiently (Lotter et al., 2003). In general, as stated by the executive director of IFOAM Markus Arbenz: "Conventional practices deplete soils and thereby undermine long term food security..." (Engllish, 2010).

Pest resistance Pests in food production systems are a serious problem as the incidence of pests negatively affects the crops' productivity. According to Oerke (2006), despite the use of pesticides, pests have still caused around $40 \%$ loss in the world potential food. Hence, a high susceptibility of crops to pests negatively affects the SFPS. The crops' resistance to pests is generally greater in organic systems compared to the conventional (Birkhofer et al., 2008). Different explanations exist. First, a greater resistance to pests can be due to the increased soil quality and enhanced microbial biomass (Birkhofer et al., 2008). Second, growing relatively slowly raises some chemical defenses in plants to a level that prevents them against most diseases and pests. This is in contrast to the conventional and more specifically biotechnological approaches where plants are allowed to grow unusually fast using much chemical nutrients whereby the accumulation of defense compounds is reduced (FAO, 2007). Third, the crops' resistance is also stimulated because of the enriched biodiversity by OA which also enhances the diversity of natural enemies (Meyling et al., 2010). This stands in contrast to conventional agriculture where extreme use of agrochemicals in combination with expanding monocultures has already intensified pest problems. Also, OA is associated with the increased species richness and abundance of predatory invertebrates and birds (Fuller et al., 2005; Hole et al., 2005). The beneficial influence of OA further accounts for invertebrate feeders (Smith et al., 2010), insect 
pollinated plants (Gabriel \& Tscharntke, 2007), bee diversity, flower cover, and plant species richness (Rundlöf et al., 2010).

Food security OA could, in the long term, also be considered as an important contributor to food security, as it addresses several issues as follow:

1. the ever increasing population growth (80 million per year according to UNFPA, 2010), especially in developing countries, asks for more efficient use of resources and less dependent methods on non-renewable resources (Azadi et al., 2010);

2. the problem of land degradation is threatening food security and is expected to be worsened (Eswaran et al., 2001);

3. taking into account climate change that calls for more adaptation of agricultural systems to extreme weather in order to keep the crops' yield sustainable (Rosenzweig \& Parry, 1994); and

4. pest management problems which threaten food security and are expected to be worsened as a result of climate change (Coakley et al., 1999).

Thereby, a shift to OA will be more and more essential in order to renew the resources (mainly water and soil) to secure food production in the future. In other words, compared to the other approaches, OA:

1. uses water more efficiently (Thierfelder \& Wall, 2009; Giller et al., 2003; Lotter et al., 2003);

2. relies much less on fossil fuels (Scialabba \& Müller-Lindenlauf, 2010);

3. prevents land degradation and even improves soil fertility (Niggli et al., 2007);

4. is more resistant to drought (Muller \& Davis, 2009; Thierfelder \& Wall, 2009; Lotter et al., 2003; Ramesh et al., 2005); 
5. produces higher yields under dry conditions (Muller \& Davis, 2009; Thierfelder \& Wall, 2009; Lotter et al., 2003; Ramesh et al., 2005);

6. includes local knowledge/varieties (Willer \& Yussefi, 2007; Muller \& Davis, 2009); and

7. is more resistant to pests (Meyling et al., 2010; Birkhofer et al., 2008; FAO, 2007).

In conclusion, a long-term transition towards OA could be encouraged. However, as OA, at least in short-term, produces lower crop yields (Maeder et al., 2002), there are some kinds of tradeoffs between organic and the two other approaches with respect to sustainability (in terms of long term potentials to produce enough food) and productivity. This means that although OA in the short-term may produce fewer, in the long-term may produce higher yields (Badgly and Perfetto, 2007) because it can better address important threats of food security such as soil degradation, climate change and pest problems. Nevertheless, we cannot ignore one billion hungers (FAO/WFP, 2010) and 3.7 billion malnourished (WHO, 2005 in Pimentel, 2011) people worldwide. Therefore, given the low productivity of OA at the present time, we still need the conventional and safe biotechnological methods to feed the hunger bellies. Accordingly, the transition should be regarded as a gradual shift to be able to challenge with the dilemma of the hungers and the malnourished people.

\section{References}

APHA, 2007. Toward a Healthy, Sustainable Food System (Policy Number: 200712). American Public Health Association. 2007-06-11. Retrieved June $14^{\text {th }} 2011$ from <http://www.apha.org/advocacy/policy/policysearch/default.htm?id=1361>

Azadi, H., Ho, P., 2010. Genetically modified and organic crops in developing countries: A review of options for food security. Biotechnology Advances 28, 160-168. 
Azadi, H., Ho, P., Hasfiati, L., 2010. Agricultural land conversion drivers: A comparison between less developed, developing and developed countries. Land Degradation \& Development DOI: 10.1002/ldr.1037.

Azadi, H., Talsma, N., Ho, P., Zarafshani, K., 2011. GM crops in Ethiopia: A realistic way to increase agricultural performance? Trends in Biotechnology 29, 6-8.

Badgly, C., Perfetto, I., 2007. Can organic agriculture feed the world? Renewable Agriculture and Food Systems 22, 80-85.

Bazuin, S., Azadi, H., Witlox, F., (in press). Application of GM crops in Sub-Saharan Africa: Lessons learned from Green Revolution. Biotechnology Advances.

Birkhofer, K., Bezemer, M.T., Bloem, J., Bonkowsk, M., et al., 2008. Long-term organic farming fosters below and aboveground biota: Implications for soil quality, biological control and productivity. Soil Biology and Biochemistry 40, 2297-2308.

Borron, S., 2006. Building Resilience for an Unpredictable Future: How Organic Agriculture Can Help Farmers Adapt to Climate Change. FAO, Rome.

Coakley, S.M., Scherm, H., Chakraborty, S., 1999. Climate change and plant disease management. Annual Review of Phytopathology 37, 399-426.

Carvalho, F.P., 2006. Agriculture, pesticides, food security and food safety. Environmental Science and Policy 9, 685-692.

Engllish, A., 2010. Powered by Nature. In Food Security (ISSN 2044-3269). Platinum Media Consulting: London. $\quad$ Retrieved January $\quad 7^{\text {th }} \quad 2011$ from <http://www.feedingthefuture.eu/FS/foodsecurity.pdf>

Eswaran, H., Lal, R., Reich, P.F., 2001. Land degradation: an overview. In: Bridges, E.M., I.D. Hannam, L.R. Oldeman, F.W.T. Pening de Vries, S.J. Scherr, and S. Sompatpanit (eds.). Responses to Land Degradation. Proc. 2nd. International Conference on Land 
Degradation and Desertification, Khon Kaen, Thailand. Oxford Press, New Delhi, India.

Fan, T., Stewart, B.A., Payne, W., Yong, W., Luo, J., Gao, Y., 2005. Long-term fertilizer and water availability effects on cereal yield and soil chemical properties in Northwest China. Soil Science Society of America Journal 69, 842-855.

FAO, 2007. Organic Agriculture and Food Utilization. FAO, Rome.

FAO, 2008. Conference on Ecological Agriculture: Mitigating Climate Change, Providing Food Security and Self-Reliance for Rural Livelihoods in Africa. Retrieved November $30^{\text {th }} 2010$ from <http://www.fao.org/docrep/012/al134e/al134e00.pdf>

FAO/WFP, 2010. The State of Food Insecurity in the World. Addressing Food Insecurity in Protracted Crisis. Rome : FAO.

FBP, 2011. The Water Resources of Earth. Retrieved July $28^{\text {th }} 2011$ from

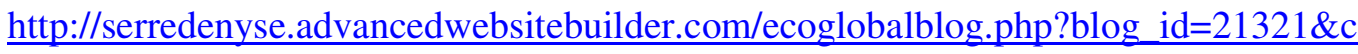
ategory_id=\&start=\&arcyear=\&arcmonth $=\&$ curyear=\&curmonth $=\&$ curday $=$

Fuller, R.J., Norton, L.R., Feber, R.E., et al., 2005. Benefits of organic farming to biodiversity vary among taxa. Biology Letters 1, 431-434.

Gabriel, D., Tscharntke, T., 2007. Insect pollinated plants benefit from organic farming. Agriculture, Ecosystems and Environment 118, 43-48.

Giller, K.E., Bignell, D., Lavelle, P., Swift, M., et al., 2003. Soil biodiversity in rapidly changing tropical landscapes: scaling down and scaling up. In Bardgett RD, MB Usher, and DW. Hopkins (eds) Biological Diversity and Function in Soils. Cambridge University Press: New York.

Hodge, I., 1993. Sustainability: putting principles into practice. An application to agricultural systems. Paper presented to 'Rural Economy and Society Study Group', Royal Holloway College, December 1993. 
Hole, D.G., Perkins, A.J., Wilson, J.D., Alexander, I.H., Grice, P.V., Evans, A.D., 2005. Does organic farming benefit biodiversity? Biological Conservation 122, 113-130.

Jenkins, J.C., Scanlan, S.J., 2001. Food security in less developed countries, 1970 to 1990. American Sociological Review 66, 718-744.

Kilcher, L., 2007. How organic agriculture contributes to sustainable development. Journal of Agriculture and Rural Development in the Tropics and Subtropics 89, 31-49.

Lal, R., 2009. Soil degradation as a reason for inadequate human nutrition. Food Security 1, $45-57$.

Lobell, D.B., Schlenker, W., and Costa-Roberts, J., 2011. Climate Trends and Global Crop Production Since 1980. Science 5 May 2011 [DOI:10.1126/science.1204531]

Lotter, D.W., Seidel, R., Liebhardt, W., 2003. The performance of organic and conventional cropping systems in an extreme climate year. American Journal of Alternative Agriculture 18, 146-154.

Maeder, P., Fließbach, A., Dubois, D., Gunst, L., Fried, P., Niggli, U., 2002. Soil fertility and biodiversity in organic farming. Science 296, 1694-1698.

Meyling, N.V., Navntoft, S., Eilenberg, J., 2010. Organic farming systems benefit biodiversity and natural pest regulation in white cabbage, retrieved $12^{\text {th }}$ of December 2010 from <http://orgprints.org/16988/1/16988.pdf>

Middleton, N., 2008. Environment today: food security. Geography Review 22, 24-26.

Muller, A., Davis, J.S., 2009. Reducing Global Warming: The potential of Organic

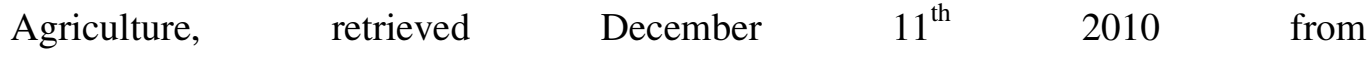
$<$ http://orgprints.org/16507/1/mueller-and-davis-2009-

ReducingGlobalWarming_PolicyBrief.pdf> 
Niggli, U., Early, J., Ogorzalek, K., 2007. Issues Paper: Organic Agriculture and Environmental Stability of the Food Supply. Retrieved $20^{\text {th }}$ December 2010 from <http://orgprints.org/10752/1/niggli-et-al-2007-environmental-stability.pdf>

Niggli, U., Schmid, H., Fließbach, A., 2008. Organic Farming and Climate Change. International Trade Centre (ITC), Geneva.

Norton, L., Johnson, P., Joys, A., Stuart, R., et al., 2009. Consequences of organic and nonorganic farming practices for field, farm and landscape complexity. Agriculture, Ecosystems and Environment 129, 221-227.

Oerke, E.-C., 2006. Crop losses to pests. Journal of Agricultural Science 144, 31-43.

Pimentel, D., 2006. Soil erosion: a food and environmental threat. Environment, Development and Sustainability 8, 1119-1137.

Pimentel, D., 2011. Food for thought: a review of the role of energy in current and evolving agriculture. Critical Reviews in Plant Sciences 30, 35-44.

Pimentel, D., Hepperly, P., Hanson, J., Douds, D., Seidel, R., 2005. Environmental, energetic, and economic comparisons of organic and conventional farming systems. BioScience $55,573-582$.

Ramesh, P., Singh, M., Rao, A.S., 2005. Organic farming: its relevance to the Indian context. Current Science 88, 561-568.

Rosenzweig, C., Parry, M.L., 1994. Potential impact of climate change on world food supply. Nature 367 (Jan), 133-138.

Rundlöf, M., Edlund, M., Smith, H.G., 2010. Organic farming at local and landscape scales benefits plant diversity. Ecography, 33, 514-522.

Sanchez, P.A., 2002. Soil fertility and hunger in Africa. Science 295(5562), 2019-2020.

Schnepf, R., 2004. Energy Use in Agriculture: Background and Issues. Retrieved $28^{\text {th }}$ July 2011 from http://www.nationalaglawcenter.org/assets/crs/RL32677.pdf 
Scialabba, N., Müller-Lindenlauf, M., 2010. Organic agriculture and climate change. Renewable Agriculture and Food Systems 25, 158-169.

Smith, H.G., Danhardt, J., Lindström, Å., Rundlöf, M., 2010. Consequences of organic farming and landscape heterogeneity for species richness and abundance of farmland birds. Oecologica 162, 1071-1079.

Smith, L.C., El Obei, A.E., Jensen, H.H., 2000. The geography and causes of food insecurity in developing countries. Agricultural Economics 22, 199-215.

Tharakan, P.J., de Castro, J., Kroeger, T., 2007. Energy sector assistance in developing countries: Current trends and policy recommendations. Energy Policy 35, 734-738.

Thierfelder, C., Wall, P.C., 2009. Effects of conservation agriculture techniques on infiltration and soil water content in Zambia and Zimbabwe. Soil and Tillage Research 105, 217-227.

UNFPA, 2010. State of World Population 2010. From Conflict and Crisis to Renewal: Generations of Change. United Nations Population Fund. Retrieved $28^{\text {th }}$ July 2011 http://www.unfpa.org/webdav/site/global/shared/swp/2010/swop_2010_eng.pdf

UNESCO, 2003. Facts and Figures: The Different Water Users. Retrieved July $28^{\text {th }} 2011$ from $\quad$ http://www.wateryear2003.org/en/ev.php$\underline{\text { URL ID }=1607 \& U R L \text { DO=DO TOPIC\&URL SECTION=201.html }}$

USDA, 2007. Food Security Assessment 2006. USDA, Washington.

Willer, H., Yussefi, M., 2007. The World of Organic Agriculture. Statistics and Emerging Trends 2007. International Federation of Organic Agriculture Movements (IFOAM): Bonn.

Ziesemer, J., 2007. Energy Use in Organic Systems. Rome: FAO. 